\title{
Teaching at Its Best: A Passionate Detachment in the Classroom
}

\section{Paul Gardner, Luther College}

$\mathrm{T}$ eachers should keep their personal opinions out of the classroom because they are teachers. Philosopher Michael Oakeshott writes that "teaching is not taming, ruling, restoring to health, conditioning, commanding, because none of these things is possible in relation to a pupil" (1989, 4-5). What do students need from their teachers? They need assistance to develop an understanding of a course's subject matter and an ability to think critically. ${ }^{1}$ Too many students come into our classrooms having been told what to think by their parents, their clergy, and their peers. Too many leave our classrooms having been told what to think by us, their teachers. The best teaching nurtures understanding of and critical thinking about subject matter by encouraging students to put aside their own personal views to free themselves to listen and to learn from others, including those they may disagree with. And this all begins with the teacher being willing to do the same.

I can best illustrate my thinking about advocacy in the classroom by describing Introduction to Social Policy, a course I teach with the following catalog description:

\begin{abstract}
More than thirty years after President Johnson declared a "War on Poverty," poverty still persists in America. What has gone wrong? Where do we go from here? This course will study the ideas of scholars who propose different answers to these questions.
\end{abstract}

After teaching this course for five years, I am still amazed at how many students come into the class with clearly conservative or liberal ideas, simply because they have never been exposed to contradictory

Paul Gardner is associate professor and head of the political science department at Luther College. He teaches courses in social policy, polifics and religion, and American politics. arguments. The first thing I tell my students on the first day of class is to leave their perspectives at the classroom door. I promise to do the same. In other words, I pledge not to advocate any one position about the causes, consequences, and solutions to poverty, the course's subject matter.

Some students are bothered by this idea of detachment. "How," they ask, "can you expect us to be neutral about poverty?" Others wonder, "How can you be neutral about a subject you teach?" But detachment doesn't mean neutrality, I tell them, and then describe the first book they will read for the course - There Are No Children Here, by Alex Kotlowitz. It is a harrowing account of two kids, Pharoah and Lafayette Rivers, growing up in Henry Horner Homes, a public housing project in Chicago. Neutrality about poverty is not possible after reading Kotlowitz because he gives a human face to the problems of drugs, crime, joblessness, welfare dependence, and fatherless families that most of us understand only through statistics.

After reading Kotlowitz, students begin to ask, "Why do things happen the way they do?" and "Why have things turned out this way?" They begin to focus on the social and economic deterioration of America's inner cities, to face one of today's most serious problems. The answers to their questions about the poverty that Kotlowitz describes, as well as other kinds of poverty, are not easy to find. In fact, social scientists disagree about the causes, consequences, and solutions to poverty. To prepare students to enter into and to learn from the scholarly arguments about poverty, they must be encouraged to separate themselves from their own convictions about this subject, to detach their thoughts from their emotions and learned behaviors.
Detachment is a way to channel a passion to know into a means of knowing. The "passionate detachment" I mentioned in the title of this essay is not an oxymoron. I am passionate about the discipline of detachment, both my own and my students', because I believe that only by putting aside ones' own convictions can one be open to learning what others have to say about a subject matter. And it is only through understanding the ideas of others that people gain a more complete understanding of a subject.

This is Nietzsche's point when he says that "the more eyes, different eyes, we can use to observe one thing, the more complete will our concept of the thing be." 2 Likewise, it is the Supreme Court's point when it says that a closer approximation to the truth is found by juries if minorities and women, as well as white men, serve on them. It is also the way of science, where knowledge advances through a process of open criticism and problem solving. Historian Thomas Haskell describes the connection between detachment and understanding this way:

Only insofar as the members of the community are disposed to set aside the perspective that comes most spontancously to them, and strive to see things in a detached light, is there any likelihood that they will engage with one another mentally and provoke one another through mutual criticism to the most complete, least idiosyncratic view humans are capable of.

$(1990,135)$

After studying Kotlowitz, students have a good sense of the "facts" of inner city poverty. We then spend a couple of classes talking about other kinds of poverty, such as the poverty of the working poor. During the remainder of the course, students engage the ideas of three social scientists who advocate different answers 
to the two questions: "What has gone wrong with the "War on Poverty'? and "Where do we go from here?" The class reads Charles Murray's Losing Ground (1984), in which he argued that America's antipoverty programs have harmed the poor and ought to be abolished. Murray's ideas about the influence of welfare on the increase in the proportion of poor children born out of wedlock formed the intellectual foundation for the 1996 welfare reform law, "The Personal Responsibility and Work Opportunity Act." This law ends America's 60-year commitment to provide cash assistance to families eligible for Aid to Families with Dependent Children.
American values, like hard work and sacrifice for the sake of one's children. He cited the Earned Income Tax Credit, available only to lowincome working Americans, as an example of an anti-poverty program even Ronald Reagan liked.

I believe students gain a better understanding of poverty by studying and evaluating the ideas of these three scholars than they would from considering the ideas of just one. Political scientist Giandomenicao Majone wrote that a multiple perspectives approach is "specifically designed to bring out unstated assumptions, differing interpretations of facts, and gaps in logic and evidence" $(1989,40)$. For example, un-

\section{Detachment is a way to channel a passion to know into a means of knowing.}

\begin{abstract}
After Murray, the class reads Ruth Sidel's Keeping Women and Children Last (1996), in which she argued that the condition of the poor has worsened not because of welfare but because of economic and social factors, such as the decline of high-paying, low-skilled factory jobs and continued racism.
\end{abstract} Sidel urges America to adopt more generous antipoverty programs, similar to those in Western European welfare states. Among the programs she suggests are a children's allowance, guaranteed health insurance, and affordable child care. Sidel's criticisms of conservative ideas about the causes, consequences and solutions to poverty were used by the liberal opponents of the 1996 welfare reform law.

Lastly, the class reads David Ellwood's Poor Support (1988), in which a middle ground is staked out between conservative advocates like Murray and liberal advocates like Sidel. Ellwood served for two years in the Clinton Administration and is best known for suggesting both time limits on welfare and generous spending to help ease former welfare recipients into the world of work. Ellwood's most useful insight was that Americans will accept more spending on the poor only if antipoverty programs are consistent with derstanding Murray's arguments about the negative consequences of welfare helps students evaluate Sidel's more positive appraisal of America's "War on Poverty." Understanding Sidel's argument about the impact of postindustrial economic trends on life in America's inner cities, helps them evaluate the dominance of welfare culpability in Murray's analysis of poverty. And, in the process of evaluating arguments and evidence, my students learn to develop their own ideas about poverty and other subjects. But I want them to understand that developing ideas means more than just having opinions.

Many teachers have heard a student dismiss their arguments or the arguments of other students with the comment "I have my opinion and you have yours," or know students who believe that the strength of their feeling about an opinion is proof of its worthiness. Understanding the assumptions behind arguments and evaluating the evidence by which arguments are built are the intellectual tools students can take out of the class and use throughout their lives. Philosopher Francis Schrag wrote that "people who care about evidence and argument seek to find out the facts and discover what's at stake in the decisions fac- ing them. ... Most important, they are willing to consider evidence, even when it challenges the doctrines they're most comfortable with" $(1995,10)$.

What I want students to take from my class is a way of understanding, not just a list of proposed causes, consequences, and solutions to poverty. As part of my research for this article, I interviewed twelve students who took my Social Policy course last semester about issues related to advocacy in the classroom. John, one of the twelve, said the following:

\begin{abstract}
If you walk into class and people say this is the way it is and you accept that, then you walk out of class and do nothing more with it. But if you are up in the air as you left it, sometimes it made me want to go out and find things out for myself. The class continues to play a part in my life because I stop and consider all three perspectives before I make decisions on things and by you keeping your views out it bothered me to the point that I wanted to get some real answers for myself. ${ }^{3}$
\end{abstract}

I do not believe students will consider ideas different from their own unless teachers work at keeping their own perspectives out of the classroom. All twelve students said that if I had told them my point of view about the subject matter, they would have been less likely to think for themselves. Two comments, one by Ann and another by Kelly, were representative:

\begin{abstract}
When a professor gives their perspective at the beginning of class I think that highly influences and inhibits the student's ability to explore and do their own critical thinking ... this is what he thinks, as long as I keep this perspective this will help my grade and I will not do the critical thinking and exploring and debating back and forth.
\end{abstract}

I felt more freedom to express my own opinions, to learn and to grow in my knowledge in different areas without having to worry about pleasing you. I didn't have to worry about writing down what you wanted to hear.

Even Sara, who at first wanted to know my point of view to make her task of figuring out what to think 
easier, came to recognize the danger in this: "I follow the professor a lot of the times and this keeps me from figuring out where I stand."

George Orwell said "good writing is like a window pane." 4 In good writing, writers do not get between the material and the reader. The same is true of good teaching. Good teachers strive to select and organize materials that present a balanced view of a course's subject and then get out of the way so that students will work the material without bias. I believe my role as a teacher is to

\section{Notes}

1. The are many books on this topic. Resnick (1987), Reich (1991), and Schrag (1995) are three of the best.

2. The Nietzsche quote is from Haskel (1990, 136).

3. The interviews took place two months

\section{References}

Ellwood, David. 1988. Poor Support: Poverty in the American Family. New York: Basic Books.

Haskell, Thomas. 1990. "Objectivity is Not Neutrality: Rhetoric vs. Practice in Peter Novick's That Noble Dream." History and Theory (May): 129-57.

Kotlowitz, Alex. 1991. There Are No Children Here. New York: Doubleday.

Majone, Giandomenicao. 1989. Evidence, Argument, and Persuasion in the Policy Process. New Haven: Yale University Press. do more than take what I know and place it into the heads of my students. I am not like a sculptor shaping and molding students into younger versions of myself. My job is to help them increase their understanding of the world and to develop their capacity to think critically. Understanding and thinking begin with the discipline of detachment, both for me and for my students. Detaching is the first necessary step to understanding arguments and evaluating evidence. Some teachers believe there is one truth and their responsibility is to find it and present it to their students. Others believe the search for truth is futile because ideas are mere masks for power. Teaching that emphasizes multiple perspectives, arguments, and evidence is an excellent middle path between the impossibility of objectivity and the nihilism of subjectivity. ${ }^{5}$ I hope my students leave my Social Policy class with the attitude that reasoned, if not final, judgments about poverty are possible and that they incorporate this belief into their approach to other intellectual as well as personal problems. after the class ended. All twelve students agreed to be interviewed and the interviews lasted between 20 and $40 \mathrm{~min}$ utes. The questions dealt with the "multiple perspectives" approach. I also asked each student whether they thought my own point of view came out. Ten said it did not.

4. The Orwell quote is from Donald Murray $(1991,151)$.

5. A similar point is made by Christopher Lasch $(1995,188-89)$.
Murray, Charles. 1984. Losing Ground: American Social Policy, 1950-1980. New York: Basic Books.

Murray, Donald. 1991. The Craft of Revision. Fort Worth: Harcourt Brace Jovanovich. Lasch, Christopher. 1995 The Revolt of the Elites and the Betrayal of Democracy. New York: W.W. Norton \& Company.

Oakeshott, Michael. 1989. The Voice of Liberal Learning. New Haven: Yale University Press.

Reich, Robert. 1991. The Work of Nations:
Preparing Ourselves For 21st Century Capitalism. New York: Alfred A. Knopf.

Resnick, Lauren. 1987. Education and Learning to Think. Washington, DC: National Academy Press.

Schrag, Francis. 1995. Back to Basics: Fundamental Educational Questions Reexamined. San Francisco: Jossey-Bass.

Sidel, Ruth. 1996. Keeping Women and Children Last: America's War on the Poor. New York: Penguin Books. 